\title{
The Nexus between Informal Relationships at Work and Employee Retention: A Review
}

\author{
K. P. Malith Priyasad ${ }^{1}$ and T. D. Weerasinghe ${ }^{2}$ \\ ${ }^{1,2}$ Department of Human Resource Management, Faculty of Commerce and \\ Management Studies, University of Kelaniya, Sri Lanka \\ ${ }^{1}$ kpmalithpriyasad@gmail.com, ${ }^{2}$ tdtmdananjaya@gmail.com \\ (iD) https://orcid.org/0000-0001-5096-6696
}

\begin{abstract}
The present paper reviews and summarizes the key findings of research on the effect of informal relationships at work on employee retention featuring the main three aspects of informal relationships at work: friendship; romance and negative relationships. Building on Maslow's (1954) hierarchy of needs theory, a narrative literature review of all the relevant research papers known to the authors was conducted. It is found that friendship at the workplace is positively correlated with employee retention whereas negative relationships at the workplace inversely effect on employee retention. However, the underline relationships between romance at the workplace and employee retention is not clear and consistent in extant literature, so that, it remains yet to be investigated further in future research studies.

The findings of the current review support the general notion that workplace is not a mere place to come and work, but it is a complex societal system through which people try to fulfill their social needs, included relationships at the workplace.
\end{abstract}

Keywords: Friendship at work; romance at work; negative relationships at work; employee retention

\section{Introduction}

Retention of the high-quality employees is more important today than ever before. A number of trends including globalization and technological advancement, make it vital. Retention of talented employees is an advantage to an organization because employees' knowledge and skills are very important to a company's ability to be competitive (Kyndt, Duchy, Michielsen \& Moeyaert, 2009). The process of employee retention will benefit an organization as the cost of employee turnover adds hundreds of thousands of money to a company's expense (Ratna \& Chawla, 2012). It also

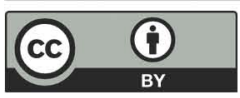


means that if a company has a higher employee retention rate, it will motivate potential employees to join the company.

The high percentage of retention rate will describe that employees will remain in the organization for the maximum period. Thus, employers should consider in retaining employees while securing their trust and loyalty, and also meet the goals of employees without losing sight of the ultimate goal of the organization (Aguenza \& Som, 2012).

As employees spend a large portion of their lives at work, informal relationships between employees at work are often formed. Informal relationships refer to the engagements or interactions among people outside the established organizational structure. Unlike formal relationships which have a set of rules and regulations which define relationship between people and the tasks, informal relationships do not follow any rules. However, they are formed by people at work, who have certain things in common; might be norms or common intentions.

Elton Mayo (1945) brought workplace relationships to attention when he wrote the first management book focusing on the social needs of employees. Mayo (1945) argued that the key determinant of job satisfaction was group interaction, and highlighted the importance of good leadership and satisfying personal relations in the workplace.

Earlier empirical research in management revealed that informal relations can sway absenteeism, work-related outcomes and behavior of employees (Riordan \& Griffeth 1995; Ross, 1997). Morrison, (2004); Sias \& Cahill, (1998) shown that informal relationships in organizations enhance employees commitment, job satisfaction and reduces absenteeism and turnover intention of employees.

The informal relationships employees have at work will have an impact beyond each individual's own sphere of experience at work. Taken together, the friendships, informal organizational relationships and unofficial power syndicates in an organization comprise the informal structure of the organization. Ringer \& Robinson (1996) stated that the informal structure is a complex, usually hidden, a network of relationships and subgroups of people that interacts with, but is different from the formal structure. In the 
informal structure, there may be strong relationships that span horizontal and vertical boundaries (Morrison, 2005).

This review paper provides definitions, mechanism and previous research findings pertaining to the informal relationships at the workplace and employee job retention. Also, this paper provides a relevant theoretical overview to give a clear idea about the variables under review. Furthermore, this paper gives a more detailed understanding of the correlation between the aforementioned two variables; informal relationships at work and employee job retention. The details about different types of informal relationship at the workplace, which are friendship at the workplace, romantic relationships at the workplace and negative relationships at the workplace, will also be discussed in the coming sub-sections of the paper.

\section{Employee Retention}

Employee retention is the effort by an employer to keep desirable workers in order to meet business objectives (Frank, Finnegan \& Taylor, 2004). Retention is voluntary moves made by an organization to create an environment in which engages employees for the long term (Chaminade, 2006). Employee job retention is a technique adopted by businesses to maintain an effective workforce and at the same time meet operational requirements (Mita, 2014). Employee retention is a process in which the employees are encouraged to remain with the organization for the maximum period or until the completion of the project (Bidisha, 2013).

Harvard Business Essentials (2002) defined retention as the converse of turnover. Employee retention and employee turnover understood as two faces of the same coin, so that, both the concepts are impossible to separate.

Employee turnover is voluntary terminations of members from organizations (Hom \& Griffeth, 1994). Staff turnover is the rate of change in the working staff of an organization during a defined period of time (Singh et al, 1994). Employee retention is different from turnover intention. Employee retention is referred to the duration of an employee to be employed in an organization while the turnover intention was meant by the amount of employee wants to leave the organization (Donoghue, 2010). 
Hale (1998), discovered that $86 \%$ of employers are suffering from attracting new employees, and 58\% of organizations complained they had difficulty in retaining employees. Even when the unemployment rate is high. Therefore, organizations are starting to specifically focus on retaining their best employees.

When a job is directly interacting with customer relationships, even the job do not need high skills or knowledge the cost of the turnover will be high and the retention of that type of employee will save customers also (Hinkin \& Tracey, 2000).

Turnover can also destroy the customer relationship with the company (Koys, 2001). Customers do not have to build a new relationship with a new employee and also customers do not have to teach about their needs to the new employees. So it is better to retain employees that will help to retain customers. (Bartlett \& Ghoshal, 2013).

Turnover costs ranging anywhere from 50 to 150 percent of in today's competitive world (Mercer Human Resource Consulting, 2004). Highperforming employees' annual salary, compounded by the skills shortage and they are looking for more than compensation packages and the ageing workforce. More specifically, what the employees nowadays accompanied by heavy replacement and training expenses. Therefore, organizations need to take a serious relook at employee retention strategies today than before (Glen, 2006).

According to SD WORX, in 2007 there was an employee turnover rate of approximately $17.46 \%$ in Belgium. For employees younger than 25 years, the employee turnover rate was 39\% (Sdworx, 2008). Those numbers illustrate the fact that the employees of the 'new' generation at work do not want a traditional career within the same company and possibly have a greater choice in pursuing careers in various companies. Losing talented employees means a loss of investment in that employee and that a new employee has to be recruited and trained. Moreover, when skilled employees leave a company, they can take a lot of confidential information to competitors (Frank et al., 2004; Walker, 2001). Also, organizations failing to retain high performers will be left with an understaffed, less qualified workforce which ultimately 
hinders the company's ability to remain competitive in the market (Rappaport et al, 2003).

Employee retention is not influenced by a single factor. In previous researchers, a number of factors associated with employee retention have been identified (Fitz-enz, 1990). Zwilling (2012) discovered that nonmonetary factors may be more effective in the long-run than financial incentives for employee retention. Padoa (2012) conducted a study among 660 American workers on what would persuade them to stay with their current employer and it was found that pay raise (43.2 \%) and non-monetary factors $(50.5 \%)$ as motivators.

Walker (2001) identified seven determinants of employee job retention: (i) compensation and appreciation of the performed work; (ii) provision of challenging work; (iii) chances to be promoted and to learn; (iv) invitational atmosphere within the organization; (v) positive relations with colleagues; (vi) a healthy balance between the professional and personal life; and (vii) the good communication.

Further, Kehr (2004) divided the retention factors into three variables: power, achievement, and affiliation. Dominance and social control represent power. When personal performance exceeds the set standards, it represents achievement and affiliation refer to social relationships which are established and intensified.

Career systems international in 2005, which surveyed over 7,500 employees about retention process and found out the attributes of retention: $48.4 \%$ exciting work/challenge, $42.6 \%$ career growth/learning, $41.8 \%$ relationships/working with great employees, $31.8 \%$ fair pay, and $25.1 \%$ supportive management/great boss.

Studies suggest that higher wages reduce quit and positively related to decisions to continue (Gritz \& Theobald, 1996). Further, Taylor (1997) pointed out that in order to retain employees, organizations must offer career advancement opportunities, work-life benefits and a supportive work climate (Behson, 2005; Casper \& Buffardi, 2004). Work-life quality has a significant relationship with job satisfaction, commitment and longer stays (Rhoades \& Eisenberger, 2002; Dixon \& Sagas, 2007). 
Studies have explained that factors such as salary and monetary benefits, working environment, interpersonal relationships and job security, job satisfaction cited as key variables that influenced employee retention in the organizations (Harris, 2000; Kinnear \& Sutherland, 2000; Maertz \& Griffeth, 2004; Meudell \& Rodham, 1998). The two-factor theory propounded by Herzberg et al. (1959) is an important theory that explains what satisfies or dissatisfies employees and hence, serves as an important framework for the employee.

In today's business scenario only high salary and designation is not significant for retaining employees in the organization, but others factors also play important role in their retention. The intent of this research is to study the relationship between employee job retention and informal relationships at workplace.

\section{Informal Relationships at Work}

The workplace relationships which have received the most research attention are those of superior-subordinate and mentor-portage. These relationships lack the voluntary aspect of friendships, as they are prescribed by the organization. They are an example of formal relationships and are therefore not a direct focus of the current study. This study focuses on informal organizational relationships, those are not prescribed by the organization (Morrison \& Wright, 2009).

Informal relationships have an effect on intention to leave because the presence of negative relationships is a reason people seek to leave their organization, but strong informal relationships make it harder for people to leave. Social involvement may be characterized as interactions and relationships with other members of the organization. This involvement is intrinsically rewarding so that the decision to leave the organization is made more difficult (Morrison, 2004).

Informal relationships and socially supportive environment at the workplace reduce the work stress and increase the organizational commitment of the employees which in turn helps to increase employee retention (Babakus, Yavas, Karatepe, \& Avci, 2003; Morrison, 2004). Informal relationships have association with employee's retention. If a person faces some conflict in the 
organization, strong relationships at the workplace cause to retain him in the organization for the longer period of time (Morrison, 2004; Winstead, 1995).

Unable to do the work (or duty) is not the only reason to leave a workplace. Being good at the work is not sufficient if unable to work with people. Thus, the informal relationships employees have at work seem to have a significant effect on several aspects of turnover, and ultimately job performance of employees (Richer et al, 2002; Riordan \& Griffeth, 1995).

\subsection{Friendship at Work}

In this study researcher focus goes to the workplace friendship, workplace friendship is focused on friendship occurred in the workplace (Song, 2005). Friendship at the workplace refers to individuals' friendship with their peers, subordinates, and superiors (Austin, 2009; Lee, 2005; Mao \& Hsieh, 2012). Friendship is a voluntary, personal relationship, typically providing intimacy and assistance, in which the two parties like each another and seek each other's company (Fehr, 1996). Workplace friendship is non-exclusive voluntary workplace relations that involve mutual trust, commitment, reciprocal liking and shared interests and values (Berman et al., 2002). Workplace friendship is a phenomenon that is beyond mere behaviors engaged in friendly ways among people in an organization, there should be trust, liking, and shared interests or values rather than being only mutual acquaintances (Berman et al., 2002).

There are basic two theories which have attempted to explain why people engage in friendships: (i) social exchange and (ii) the intrinsic quality of friendship.

Social exchange theory describes whether we like somebody, or want to engage in a friendship with him or her, is determined by the cost-reward ratio. (Rook, 1984). Social exchange theory holds that people enter into relationships because of the rewards (benefits, fulfilled needs and other privileges) that such relations are expected to bring.

According to intrinsic quality of friendship, there is no doubt that friendships are formed and maintained because they are rewarding friendships that develop beyond superficial levels often have an intrinsic 'end in themselves'. Each person perceives the other as being unique and irreplaceable. These 
friendships involve individuals whose participation transcends the importance of any easily specified set of rewards (Clark \& Mills, 1 979; Wright, 1984).

Fritz (1997) conducted a study comparing men's and women's peer relationships in organizations, surveying 666 employees resident in USA. Fritz (1997) found that women's organizational relationships have the potential to be stronger and, among very close friends, are characterized by greater intimacy than those of men. In addition, men's workplace relationships were found to be characterized by more mutual dependence and involved more activities than women's (Lee, 2011).

According to Fine (1986), workplace friendship helps individuals to reduce work stress, and provide increased communication, cooperation, and energy. Hamilton (2007) described that when a person engages in a friendship at work, that person might feel comfortable with their workplace and reduce feelings of insecurity and uncertainty. Jehn and Shah (1997) further argued that employees in a friendship exchange words of encouragement, confidence, trust, respect, and critical feedback, which may increase enthusiasm and a positive attitude. When employees have trustful friends at work, they can get help or advice from their friend co-workers and, therefore, gain feelings of security, comfort, and satisfaction with their job at work (Dotan, 2007).

Employees who have a best friend at work reported that they work with passion and feel a profound connection to the company, compared with those who have no best friend/s. Also, employees who had a best friend at work planned to be with the company for at least another year, compared to who didn't have a best friend (Roth, 2006).

People who satisfied with their job has always good relationships and friendships at the workplace. (Winstead, Derlega, Montgomery \& Pilkington, 1995). When there is a friendship at the workplace, there is some evidence that there are positive outcomes, good communication (Kram \& Isabella, 1985), increased job satisfaction (Winstead et al. 1995), job performance (Ross, 1997), reduced turnover intention, high retention (Morrison, 2004), and organizational commitment (Nielsen et al, 2000). 


\subsection{Romance at Work}

Workplace romance is mutually desired relationships involving sexual attraction between two employees of the same organization (Pierce \& Aguinis, 2001). Romantic relationships at the workplace are consensual and mutually welcomed (Clarke, 2006). Ariani (2011) explained that workplace romances are characterized by desiring to be with the other person and feelings of emotional and physical attraction, which may lead to a sharing of personal information, mutual caring and respect, and quite likely sexual behavior such as touching, kissing and hugging, and sexual intercourse (Pierce et al, 1996). Lickey (2009) described workplace romance as working together allows people to get to know each other and as familiarity grows, workplace romances may be more likely to occur. These relationships may form between peer co-workers, supervisors, subordinates, or even with company clients (Rabin-Margaloith, 2006).

More recent evidence suggests that love relationships are distinct from friendship. Lamm \& Wiesmann (1997) conducted a survey among German students in which the respondents were asked to write down how they could tell if they liked someone, loved someone, or were in love with someone. The researchers found that the most distinctive characteristic of 'liking' was wanting to interact socially with the other; the most distinctive characteristic of 'love' was trusting the other, and the most distinctive characteristic of being 'in love' was arousal. Both liking and love were associated with a positive mood in the other's presence. Bridge \& Baxter (1992) also state that sufficient research exists to suggest that friendship and love relationships are distinct relational types in extant literature.

Only two types of the workplace romance are identified in the literature, lateral and hierarchical (Karl \& Sutton, 2000; Pierce \& Aguinis 1997). A lateral romance is a relationship between employees of equal status. A hierarchical romance is one where the two employees are at different organizational levels, as when a manager is romantically involved with his or her subordinate/s. Hierarchical workplace romances are more frequent, also more problematic than lateral romances, involve power differences between those in the partnership, and are often becomes a source of hostility (Powell, 2001). 
The workplace romance literature has been fairly silent on the topic of samesex romance (Powell \& Foley, 1998). Rumens (2008) discussed homosexual friendships at work, and Bowring and Brewis (2009) look at how homosexual employees manage their identities at work. But no one has examined it as a workplace romance.

Swartz et al. (1987) concluded that overt sexual behavior and business do not mix. Strong sexual attractions interfere with work. Quinn (1977) drawing on a survey asking about romance among co-workers, found that most employees cite negative consequences from workplace romance and say that organizations generally do not take effective action. Job productivity can be negatively affected by romance due to long lunches, extended discussions behind closed doors, missed meetings, late arrivals and early departures (Quinn \& Judge 1978).

Negative effects also include co-worker disapproval, cynicism, and hostility (Anderson \& Fisher, 1991), as well as concerns that there will be favoritism and employment benefits given to one party in the relationship by the other (Anderson \& Hunsaker, 1985). Negative outcomes include conflicts of interest, flawed or biased decision-making and other workplace inequities that have a negative impact on both individual and organizational performance as well as the career of one or both partners in the relationship (Powell, 1993).

In opposition to the above perspective several researches have shown that employees involved in a workplace romance can be more productive at work (Quinn \& Lees, 1984; Dillard, 1987; Dillard \& Broetzmann, 1989; Pierce, 1998). Levels of productivity may be lower at the start of the relationship as large amounts of time and energy are invested in it. Once the initial excitement of the new romance lessens, productivity tends to rise steadily (Pierce et al, 1996). Those who show a love motive avoid the negative consequences of inadequate performance by demonstrating increased effort in order to impress their supervisors. Job satisfaction and organizational commitment also increase (Pierce \& Aguinis 2003). Workplace romance that lead to marriage could help individuals to work to their maximum potential as their personal needs are being satisfied, this in turn, benefits performance (Mainiero, 1989). 
There are positive outcomes of organizational romance for others too. For example, workplace romance can increase workplace morale and motivate other employees, encourage creativity and innovation. It can create more relaxed and happier work environments (Biggs et al., 2012) and can soften personality conflicts because the workplace romance partners are more content and easier to get along with. It can improve teamwork, communication, and cooperation (Cole, 2009). In addition, some organizations experience lower turnover, because married employees who work in the same company tend to stay with the company (Wilson, Filosa, \& Fennel, 2003).

\subsection{Negative Relationships at Work}

This is not a friendship relationship. The interaction between individuals with a negative relationship is characterized by disrespect, disagreement, dislike, conflict and/or animosity. Individuals may interact with each other on a fairly regular basis but would definitely not continue the relationship if they did not work together.

Friendships can degrade and turn sour. When this happens in a workplace the individuals concerned often have to continue to interact. Although no standard definition for such relationships yet exists, they can be characterized by conflict and disagreement, with communication ranging from " ... passive to active dislike, animosity, disrespect, or destructive mutual interaction" (Dillard \& Fritz, 1995). Such relationships have been shown to affect both individuals (Rook, 1984) and organizations (Dillard \& Fritz, 1995) adversely, causing stress and turnover.

In line with the above perspective, Andersson \& Pearson (1999) also described a negative relationship as a one where interactions such as concealment, manipulation, conflict, disrespect, disagreement, incivility and/or animosity are frequent.

Sias, et al. (2004) outlined five specific causes for negative relationships; personality, distracting life events, conflicting expectations, promotion, and betrayal. Additionally, people may obstruct others for the reasons of jealousy/professional jealousy (Cohen-Charash, 2001). 
Johnson \& Indvik (2001) found that dealing with the conflict between workers due to negative relationships might account for as much as $13 \%$ of a manager's time, or nearly seven weeks per year per manager.

Negative relationship is a reason for people seeking to leave their organization. Negative relationships could increase intention to turnover, and reduce retention intention, and also produce stress at work (Riordan \& Griffeth, 1995). The presence of negative relationships is likely to be negatively associated with employee retention, if people experience negative relationships at work they are more prone to leave the job (Kathleen \& Morrison, 2005).

Donovan, Drasgow \& Munson (1998) found that people try to quit as soon as possible when there is a serious negative problem with relationships at work. This finding was supported by Moerbeek and Need (2003), who found that people who experience a bad atmosphere at work leave more quickly than people who experience a good work atmosphere.

\section{Theoretical Overview}

The work of Maslow (1954), developed a five-level hierarchy of human needs, ranging from basic physiological needs, security needs, social needs, esteem needs, and self-actualization needs. Maslow's theory contends that; as lower level needs (such as physiological and security needs) are satisfied, higher level needs (such as esteem and self-actualization needs) emerge as motivators. For instance, one cannot motivate another to achieve their sales target (level four in the hierarchy) when they're having problems with their marriage life relationship needs (level three in the hierarchy).

The current review discusses the relationship between, the third pillar of Maslow's (1954) hierarchy of needs and employee retention. Maslow's (1954) 'Hierarchy of Needs' is an example of human motivation, something every human possesses. Humans are motivated by these needs in many aspects of life, including their work lives. Because these needs are transferable to the workplace, understanding these needs and motivation can help organizations improve employee retention by better understanding of employee wants and needs. The third layer/level of the pyramid (needs hierarchy) refers to the basic human need for friendship, intimacy, and 
familial bonds. While at first glance this may not seem very transferrable, it is actually a very important aspect of the organizational atmosphere. Employees want relationships at work. They want to form relationships with their co-workers and management, and they want to be able to feel supported. Company events and forming a collaborative atmosphere will help employees to form that connection they want to the people they work with and for.

After Maslow published his hierarchy of needs theory in 1954, Herzberg, Mausner, and Snyderman (1959) wrote about the motivation to work, which describes how employee satisfaction stems from factors such as achievement, recognition for accomplishment, challenging work, increased responsibility and opportunities for growth and development. Herzberg's (1966) two-factor theory of job satisfaction was influential in the development of many subsequent measurement tools (Tovey \& Adams, 1999). Herzberg et al. (1959) postulated that satisfaction and dissatisfaction are two separate phenomena. Intrinsic factors are the factors intrinsic to the nature and experience of doing work, which they found to be job satisfiers, include; achievement, recognition, work itself and responsibility. They named these factors as motivators. Extrinsic factors, which they found to be job 'dissatisfies' include; company policy, administration, supervision, salary, interpersonal relations and working conditions. They named these as hygiene factors. Herzberg maintained that hygiene factors counteract physical needs and can avoid discomfort, but cannot produce pleasure. On the other hand, the satisfiers of psychological needs (motivators) can produce pleasure, but their absence does not produce discomfort. Herzberg viewed the two dimensions of satisfaction and dissatisfaction as independent of each other. Consequently, it is possible to be simultaneously satisfied and dissatisfied with different aspects of the same job.

\section{Informal Relationships at Work and Employee Retention}

Informal relationships can have the certain association with employee's retention. If a person faces some conflict in the organization; strong relationships at the workplace cause to retain him in the organization for the longer period of time (Morrison, 2004; Winstead, 1995). An American study by Lozada (1996) found that $90 \%$ of dismissals are the result of poor attitudes, inappropriate behavior, and difficulties with interpersonal relationships rather than deficient technical skills. 
Empirical studies (Harris, 2000; Kinnear \& Sutherland, 2000; Maertz \& Griffeth, 2004; Meudell \& Rodham, 1998) have explained that some factors that increase retention, which includes friendly working environment and healthy personal relationships. Allen and Shanock (2013) also stressed on the relationship with colleague socialization, increase an organization retention capability.

Earlier empirical research in management sciences revealed that positive informal relations have a positive relationship with employee retention (Riordan \& Griffeth 1995; Ross, 1997). Morrison, (2004); Sias \& Cahill, (1998) have shown that informal relationships in the organizations enhance employees retention through job satisfaction. Walker (2001) identified seven factors that can enhance employee retention that included positive relations with colleagues. Kehr (2004) noted that social relationships have a relationship with employee retention.

Career Systems International in 2005, which surveyed over 7,500 employees about retention process and found out the attributes of retention: $41.8 \%$ declared relationships/working with great employees have an impact on retention decision. Empirical studies have been conducted on workplace friendship, there is some evidence that they are related to positive outcomes such as reduced turnover intention (Morrison, 2004). If a person experiences a personal crisis or has a very stressful job, workplace friends can provide support and therefore decrease the chances of the turnover (Morrison, 2004).

There are also many direct influences of friendship and informal relationships at the workplace. Morrison (2004) lists in his theoretical study six main factors and focuses on their mutual influences. These factors are friendship opportunities, cohesion, friendship prevalence, job satisfaction, organizational commitment and intention to leave. Dotan (2007) concludes Morrison's studies and deals with the direct effect of friendship on these factors according to the pillars of friendship. 


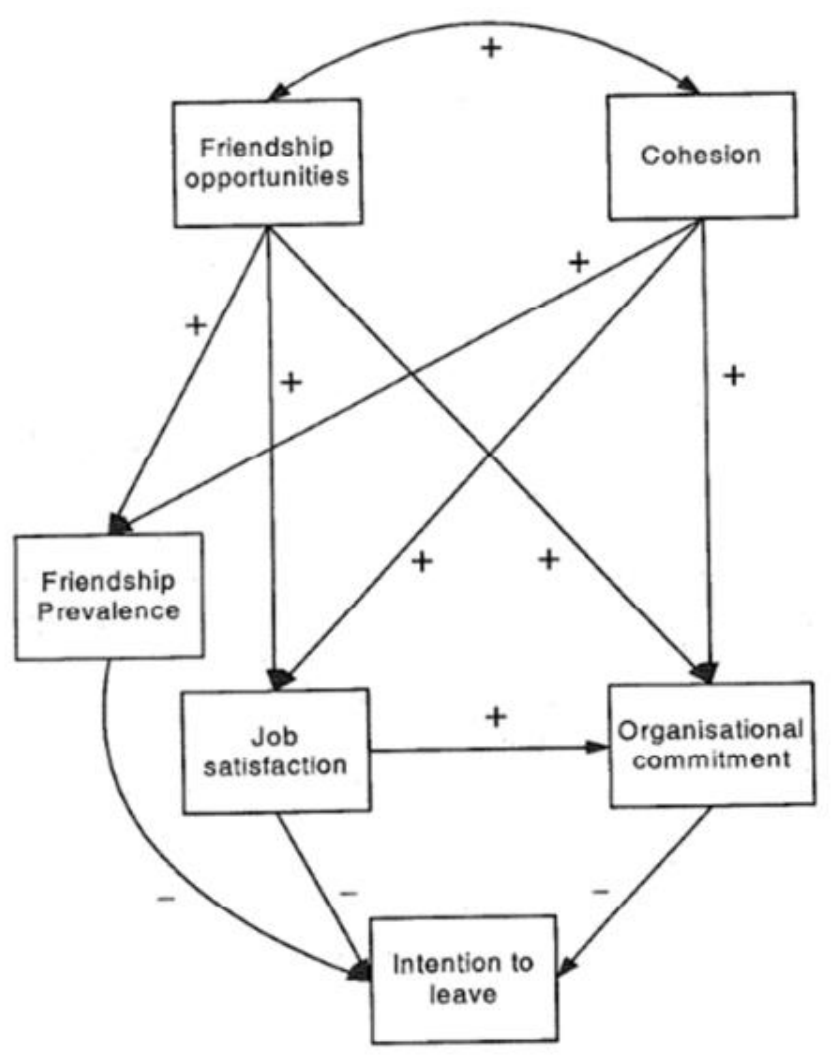

\section{Figure 01: Influence of Informal Relationships at Work}

Source: Adapted from Morrison (2004)

Morrison (2004) presents a theoretical/conceptual model of direct and indirect influence of friendship at work on organizational factors as shown in figure 01 , three of the factors negatively influence the intention to leave the workplace; namely organizational commitment, job satisfaction and friendship prevalence; thus failure of one of these factors might increase the employee's intention to leave. The main factors are the organizational commitment and job satisfaction in the aforementioned model. Therefore, failure of one of those factors leads almost inevitably to intention to leave, whilst friendship prevalence only decreases it. Dotan (2007) study suggests that instrumentality and work safety/trust have the main impact on the intention to leave. 
In order to explain the reasons behind the voluntary resignation, Arthur (2001) gave a list, which includes unsatisfactory relationships at work as a prominent reason. Presence of negative relationships is a reason to turnover, or at least produce stress at work which, in turn, can cause other problems (Riordan \& Griffeth, 1995). The presence of negative relationships is likely to be negatively associated with employee retention if people experience negative relationships at work they are more inclined to leave their job (Kathleen \& Morrison, 2005).

\section{Conclusion}

Having reviewed the above reported empirical findings up to date and theoretical explanations building on Maslow's (1954) hierarchy of needs theory, it could be concluded that informal relationships at work significantly effect on employee retention. Further, it is found that friendship at the workplace is positively correlated with employee retention whereas negative relationships at the workplace inversely effect on employee retention. However, the underline relationships between romance at the workplace and employee retention is not clear and consistent in extant literature, so that, it remains yet to be investigated further in future research studies.

\section{References}

Allen, D., \& Shanock, L. (2013). Perceived Organizational Support and Embeddedness as Key Mechanisms Connecting Socialization Tactics to Commitment and Turnover among New Employees. Journal of Organizational Behaviour, 350-370.

Anderson, C., \& Fisher, C. (1991). Male-female relationships in the workplace: Perceived motivations in office romance. 163-180.

Anderson, C., \& Hunsaker, P. (1985). Why there's romancing at the office and why it's everybody's problem. 57-63.

Anderson, L., \& Pearson, C. (1999). Tit for tat? The spiraling effect of incivility in the workplace. The Academy of Management Review, 24(3).

Appelbaum, S., Marinescu, A., Klenin, J., \& Bytau. (2007). Fatal attractions: The (mis) management of workplace romance. International Journal of Business Research, 7, 31-43. 
Ariani, M., Ebrahimi, S., \& Saeedi, A. (2011). Managing workplace romance; a headache for human resource leaders. 3rd International Conference on Advanced Management Science.

Arthur, D. (2001). The Employee Recruitment and Retention Handbook. New York: Amacom.

Austin, C. (2009). An investigation of workplace friendships and how it influences career advancement and job satisfaction: A qualitative case study. Unpublished PhD's Thesis, Capella University.

Behson, S. (2005). The relative contribution of formal and informal organizational work-family support. Journal of Vocational Behavior.

Berman, E., West, J., Maurice, W., \& Richter. (2002). Workplace relations: Friendship patterns and consequences. Public Administration Review, 62, 217-230.

Bidisha, L., \& Mukulesh, B. (2013). Employee Retention: A Review of Literature. Journal of Business and Management, 14, 8-16.

Biggs, D., Mathewman, L., \& Fulz, C. (2012). Romantic relationships in organizational settings: Attitudes on workplace romance in the UK and USA. Gender in Management: An International Journal, 27, 271-285.

Bowring, M., \& Brewis, J. (2009). Truth and consequences: Managing lesbian and gay identity in the Canadian workplace. Equal Opportunities International, 28, 361-377.

Bridge, K., \& Baxter, L. (1992). Blended relationships: Friends as work associates. Western Journal o/Communication, 56(3), 200-225.

Casper, W., \& Buffardi, L. (2004). Work-life benefits and job pursuit intentions: The role of anticipated organizational support. Journal of Vocational Behavior.

ChaminadE, B. (2006). A retention checklist: how do you rate? Retrieved from http://www.humanresourcesmagazine.co.au.

Clark, M., \& Mills, J. (1979). Interpersonal attraction in exchange and communal realtionships. Journal of Personality and Social Psychology, 12-23.

Clarke, L. (2006). Sexual relationships and sexual conduct in the workplace. Legal Studies, 347-368. 
Cohen-Charash, Y., \& Spector, P. (2001). The role of justice in organizations.

Cole, N. (2009). Workplace romance: A justice analysis. Journal of Business Psychology, 24, 363-372.

Dillard, J. (1987). Close relationships at work: Perceptions of the motives and performance of relational participants. Journal of Social and Personal Relationships, 4, 179-193.

Dillard, J., \& Broetzmann, S. (1989). Romantic relationships at work: Perceived changes in job-related behaviours as a function of participant's motive, partner's motive and gender. Journal of Applied Social Psychology, 19, 93110.

Dillard, J., \& Fritz, J. (1995). Interpersonal relationships and organizational performance. Annual Convention of the Western Speech Communication Association. Portland.

Dixon, M., \& Sagas, M. (2007). The Relationship between organizational support, work-family conflict, and the job-life satisfaction of university coaches. Research Quarterly for Exercise and Sport.

Donoghue, C. (2010). Nursing Home Staff Turnover and Retention: An Analysis of National Level Data. Journal of Applied Gerontology.

Donovan, M., Drasgow, F., \& Munson, L. (1998). The Perceptions of Fair Interpersonal Treatment Scale: Development and Validation of a Measure of Interpersonal Treatment in the Workplace. Journal of Applied Psychology, 83(5).

Dotan, H. (2007). Friendship ties at work: Origins, evolution and consequences for managerial effectiveness. Unpublished Doctoral Dissertation, University of California, Los Angeles.

Eisenberger, R., Stinglhamber, F., Vandenberghe, C., Sucharski, I., \& Rhoades, L. (2002). Perceived Supervisor Support: Contributions to Perceived Organizational Support and Employee Retention. Journal of Applied Psychology, 87.

Frank, F., Finnegan, R., \& Taylor, C. (2004). The race for talent: retaining and engaging. Human Resource Planning, 27(3), 12-25.

Fritz, J. (1997). Men's and women's organizational peer relationships: A comparison. The Journal o/Business Communication, 34(1), 27-46. 
Glen, C. (2006). Key skills retention and motivation: the war for talent still rages and retention is the high ground. Industrial and Commercial Training, 38(1), 37-45.

Griffeth , R., Hom, P., \& Gaertner, S. (2000). A meta-analysis of antecedents and correlates of employee turnover: update, moderator tests, and research implications for the next millennium. Journal of Management, 26(3).

Gritz, R., \& Theobald, N. (1996). The Effects of School District Spending Priorities on Length of Stay in Teaching. Journal of Human Resources, 31(3).

Gritz, R., \& Theobald, N. (1996). The Effects of School District Spending Priorities on Length of Stay in Teaching. Journal of Human Resources.

Hale, J. (1998). Strategic Rewards: Keeping your best talent from walking out the door. Compensation \& Benefits Management., 14(3), 39-50.

Hamilton, E. (2007). Firm friendship: Examining functions and outcomes of workplace friendship among law firm associates. Unpublished Doctoral Dissertation, Boston College, Boston.

Harris, J. (2000). Finding and keeping great employees.

Harvard Business Essentials. (2002). Hiring and keeping the best people . Boston: Harvard Business School Press.

Herzberg, F. (1966). Work and the nature of man. Cleveland: World.

Herzberg, F., Mausner, B., \& Snyderman, B. (1959). The motivation to work. New York: Wiley.

Hinkin, T., \& Tracey, J. (2000). The cost of turnover. . Cornell Hotel and Restaurant Administration Quarterly, 41(3).

Jehn, K., \& Shah, P. (1997). Interpersonal relationships and task performance: An examination of mediating processes in friendship and acquaintance groups. Journal of Personality and Social Psychology, 72, 775-790.

Johnson, P. R., \& Indvik, J. (2001). Slings and arrows of rudeness: incivility in the workplace. Journal of Management Development, 20(8).

Karl, K., \& Sutton, C. (2000). An examination of the perceived fairness of romance policies. Journal of Business and Psychology, 14, 429-442. 
Kathleen, R., \& Morrison, L. (2005). Informal Relationships in the W orkplace: Associations with Job Satisfaction, OrganIsational Commitment and Turnover Intentions.

Kehr, H. (2004). Integrating implicit motives, explicit motives, and perceived abilities. The compensatory model of work motivation and volition. Academy of management review.

Kinnear, L., \& Sutherland, M. (2000). Determinants of organisational commitment amongst knowledge workers. South African Journal of Business Management, 31(3), 106-112.

Koys, D. (2001). The effects of employee satisfaction, Organizational citizenship behavior and turnover on organizational effectiveness: A unit-level, longitudinal Study. 54: pp. 101-114. Personnel psychology, 54.

Kram, K., \& Isabella, L. (1985). Mentoring alternatives: The role of peer relationships in career development. Academy a/Management Journal, 28(1).

Kyndt, E., Dochy, E., Michielsen, M., \& Moeyaert, B. (2009). Employee Retention: Organisational and Personal Perspectives.

Lamm , H., \& Weismann , U. (1997). Subjective Attributes of Attraction: How People Characterize Their Liking, Their Love, and Their Being in Love.

Lee, H. (2005). Exploration of the relationship between friendship at work and job satisfaction: An application of balance theory. Unpublished Master's Thesis, Michigan State University.

Lee, J., \& Hoon, J. (2011). Effects of Workplace Friendship on Employee Job Satisfaction, Organizational Citizenship Behavior, Turnover Intention, Absenteeism, and Task Performance.

Lickey, N., Berry, G., \& Whelan-Berry, K. (2009). Responding to workplace romance: A proactive and pragmatic approach. Journal of Business Inquiry: Research, Education \& Application, 8(1), 100-119.

Lozada, M. (1996). Social misfits, workplace outcasts. Vocational Educational Journal.

Maertz, C., \& Griffeth, R. (2004). Eight motivational forces and voluntary turnover: A theoretical synthesis with implications for research. Journal of Management, 30(5). 
Mainiero, L. (1989). Office Romance: Love, Power and Sex in the Workplace. New York: Rawson Associates.

Mao, H., Hsieh, A., \& Chen, C. (2012). The relationship between workplace friendship and perceived job significance. Journal of Management and Organization, 18(2), 247-262.

Maslow, A. (1954). Motivation and personality. New York: Harper \& Row.

Mat Som, A., \& Aguenza, B. (2012). Motivational Factors of Employee Retention and Engagement in Organizations. International Journal of Advances in Management and Economics, 1(6), 88-95.

Mayo, E. (1945). The social problems of industrial civilisation. Harvard: Harvard University Press.

Mercer Human Resource Consulting. (2009). Benefits of retaining a good staff. Mercer Human Resource Consulting Australia.

Meudell, K., \& Rodham, K. (1998). Money isn’t everything - or is it? A preliminary research study into money as a motivator in the licensed house sector. Int. J. Cont. Hosp. Manage.

Mita, M., Aarti, K., \& Ravneeta, D. (2014). Study on Employee Retention and Commitment. International Journal of Advance Research in Computer Science and Management Studies, 154-164.

Moerbeek, H., \& Need, A. (2003). Enemies at work: Can they hinder your career? Social Networks.

Morrison, R. (2004). Informal relationships in the workplace: Associations with job satisfaction, organisational commitment and turnover intentions. New Zealand Journal of Psychology, 33.

Morrison, R. (2005). Informal Relationships in the Workplace: Associations with Job Satisfaction, Organizational Commitment and Turnover Intentions. Doctoral Dissertation, Albany.

Morrison, R., \& Wrifht, S. (2009). Friends and enamies in organization. Basingstoke: Palgrave Macmillan.

Nielsen, J., Jex, S., \& Adams, G. (2000). Development and validation of scores on a twodimensional workplace friendship scale. Educational and Psychological Measurement, 60, 628-643. 
Padoa , C. (2012). The Other 3 R's: Recognition, Remuneration and Retention. Retrieved from BusinessWeek: http://bx.businessweek.com.

Pierce, C. (1998). Factors associated with participating in a romantic relationship in a work environment. Journal of Applied Social Psychology, 28.

Pierce, C., \& Aguinis, H. (1997). Bridging the gap between romantic relationships and sexual harassment in organizations. Journal of Organizational Behavior, 18, 197- 200.

Pierce, C., \& Aguinis, H. (2001). A framework for investigating the link between workplace romance and sexual harassment . Group and Organization Management, 26, 206-229.

Pierce, C., \& Aguinis, H. (2003). Romantic relationships in organizations: A test of a model of formation and impact factors. Management Research, 1, 161169.

Pierce, C., Byrne, D., \& Aguinis, H. (1996). Attraction in organizations: A model of workplace romance. Journal of Organizational Behavior, 5-32.

Powell, G. (1993). Women and Men in Management. Newbury Park: Sage.

Powell, G. (2001). Workplace romances between senior-level executives and lowerlevel employees: An issue of work disruption and gender.

Powell, G., \& Foley, S. (1998). Something to talk about: Romantic relationships in organizational settings. Journal of Management, 24, 421-448.

Quinn, R. (1977). Coping with Cupid: The formation, impact and management of romantic relationships in organizations. Administrative Science Quarterly, 22.

Quinn, R., \& Judge, N. (1978). The office romance: No bliss for the boss. Management Review.

Quinn, R., \& Lees, P. (1984). Attraction and harassment: The dynamics of sexual politics in the workplace. Organizational Dynamics, 35-46.

Rabin-Margalioth, S. (2006). Love at Work. Journal of Gender Law \& Policy, 237254.

Rappaport, A., Bancroft, E., \& Okum, L. (2003). The aging workforce raises new talent management issues for employers. Journal of Organizational Excellence, 23, 55-66. 
Rath, T. (2006). Vital friends. New York: Gallop Press.

Ratna, R., \& Chawla, S. (2012). Key Factors of Retention and Retention Strategies in Telecom Sector. Global Management Review, 6(3), 35-46.

Rhoades, L., \& Eisenberger, R. (2002). Perceived organizational support: A review of the literature. Journal of Applied Psychology.

Richer, S., Blanchard, U., \& Vallerand, R. (2002). A motivational model of work turnover. Journal of Applied Social Psychology.

Ringer, T., \& Robinson, P. (1996). Focus and strategic action in management: using a systemic model of organisational culture to inform managerial actions.

Riordan, C., \& Griffeth, R. (1995). The opportunity for friendship in the workplace: An underexplored construct. Journal of Business and Psychology, 10, 141154.

Rook, K. (1984). The negative side of social interaction: Impact on psychological well being. Journal of Personality and Social Psychology. Journal of Personality and Social Psychology, 46.

Ross, J. (1997). Does friendship improve job performance? Harvard Business Review, 75, 6-8.

Roth, W. (2006). Conversation analysis: Deconstructing social relations in the making. Rotterdam: Sense Publishers.

Rumens, N. (2008). Working at intimacy: Gay men's workplace friendship. Gender Work and Organization, 9-30.

Sias, P., \& Cahill, D. (1998). From coworkers to friends: The development of peer friendships in workplace. Western Journal of Communication, 62, 273-299.

Sias, P., Heath, R., Perry, T., Silva, D., \& Fix, B. (2004). (2004). Narratives of Workplace Friendship Deterioration. Journal of Social and Personal Relationships, 21.

Singh, J., Goolsby, J., \& Rhoads, G. (1994). Behavioral And Psychological Consequences of Boundary Spanning Burnout for Customer Service Representatives. Journal of Marketing Research, 31(4). 
Song, S. (2005). Workplace friendship and its impact on employees' positive work attitudes: A comparative study of Seoul City and New Jersey State government public officials. Unpublished Doctoral Dissertation, The State University of New Jersey, New Jersey.

Sutherland, J. (n.d.). Job-to-job turnover and job to-non- employment movement. 2000, 710-721.

Swartz, R., Warfield, A., \& Wood, D. (1987). Co-worker romances: Impact on the work group and on career oriented women. Personnel.

Taylor, S. L., \& Cosenza, R. M. (1997). Internal marketing canreduce employee turnover.

Tovey, E., \& Adams, A. (1999). The changing nature of nurses' job satisfaction: an exploration of sources of satisfaction in the 1990s. Journal of Advanced Nursing.

Walker, J. (2001). Zero defections? Human Resource Planning, 24, 6-8.

Wilson, R., Filosa, C., \& Fennel , A. (2003). Romantic Relationships at Work: Does Privacy Trump the Dating Police? Defense Counsel Journal.

Winstead, B., Derlega, V., \& Montgomery, M. (1995). The quality of friendship at work and job satisfaction. The Journal of Social and Personal Relationships, 199-215.

Winstead, B., Derlega, W., \& Montgomery. (1995). The quality of friendships at work and job satisfaction. Journal of Social and Personal Relationships, 12(2), 199-215.

Wright, P. (1984). Self-referent motivation and the intrinsic quality of friendship. Journal of Social and Personal Relationships, 115-130.

Zwilling, M. (2012). 8 Ways Leaders Can Motivate Employees Beyond Money. Retrieved from Forbes: http://www.forbes.com. 